\title{
2: 204558017-204564189
}

National Cancer Institute

\section{Source}

National Cancer Institute. 2:204558017-204564189. NCI Thesaurus. Code C42018.

Physical location of CT LA4_Gene 